\title{
PERLINDUNGAN HUKUM KONSUMEN JASA PARKIR DITINJAU DARI HUKUM POSITIF
}

\author{
Edi Yanto ${ }^{1}$ \\ Dosen Fakultas Hukum Universitas Muhammadiyah Mataram \\ E-mail:Edidinata85@gmail.com \\ Imawanto $^{2}$ \\ Dosen Fakultas Hukum Universitas Muhammadiyah Mataram \\ E-mail: Imawanto123@gmail.com \\ Tin Yuliani ${ }^{3}$ \\ Dosen Fakultas Hukum Universitas Muhammadiyah Mataram \\ E-mail:yulianitin@gmail.com \\ DOI: https://doi.org/10.31764/mk:\%20jih.v11i1.2264
}

Received: Feb 1, 2020, Accepted: Feb 28, 2020 /Published: April 30, 2020

\begin{abstract}
This article discusses the related problem of frequent loss of goods or vehicles in the parking area, causing disputes between consumers and parking managers. Most parking attendants do not want to be blamed for the loss of goods or consumer vehicles. Parking service managers always use the excuse that their work complies with the agreement or clause stated in the parking ticket, that is, "the parking manager is not responsible for the loss of goods and / or vehicles". Implementation and inclusion of standard clauses on parking tickets places the parties in an unequal position. This can be used by business actors to make a profit. This type of research uses normative legal research with a statutory approach. The results of the study, that the form of legal protection for consumers of parking services in terms of a positive law, is the parking manager is obliged to guarantee the security and safety of objects of safekeeping agreement for a specified period. In the event of damage or loss of object for safekeeping, the parking manager is responsible for providing compensation.

Keywords:, consumers, legal protection, services, parking
\end{abstract}

\begin{abstract}
Abstrak
Artikel ini membahas persoalan terikait sering terjadinya kehilangan barang atau kendaraan di areal parkir, sehingga menimbulkan perselisihan antara konsumen dengan pengelola parkir. Kebanyakan petugas parkir tidak mau disalahkan atas hilangnya barang atau kendaraan konsumen. Pengelola jasa parkir selalu menggunakan alasan bahwa pekerjaanya telah sesuai dengan perjanjian atau klausula yang tertuang di karcis parkir, yakni, "pengelola parkir tidak bertanggung jawab terhadap kehilangan barang dan/atau kendaraan". Pelaksanaan dan pencantuman klausula baku pada karcis parkir, menempatkan para pihak pada kedudukan yang tidak seimbang. Hal tersebut dapat dimanfaatkan oleh pelaku usaha untuk memperoleh keuntungan. Jenis
\end{abstract}


penelitian ini menggunakan penelitian hukum normatif dengan pendekatan perundang-undangan. Hasil penelitian, bahwa bentuk perlindungan hukum bagi konsumen jasa parkir ditinjau dari hukum positif, adalah pengelola parkir wajib menjamin keamanan dan keselamatan obyek perjanjian penitipan barang selama jangka waktu yang ditentukan. Apabila terjadi kerusakan atau kehilangan obyek penitipan barang, maka pengelola parkir wajib bertanggung jawab untuk memberikan ganti rugi.

Kata Kunci: jasa, konsumen, parkir, perlindungan hukum

\section{PENDAHULUAN}

Selama ini, pengelolaan parkir bukan tanpa masalah, seringnya terjadi kehilangan barang atau kendaraan di areal parkir menyebabkan maraknya terjadi perselisihan antara konsumen dengan petugas parkir. Kebanyakan petugas parkir tidak mau disalahkan atas hilangnya barang atau kendaraan konsumen. Bukan saja petugas parkir, pengelola jasa parkir juga tidak ingin ambil risiko jika terjadi kehilangan barang pada konsumen. Pengelola jasa parkir selalu menggunakan alasan bahwa hal tersebut telah sesuai dengan perjanjian atau klausula yang mengikat antara pengelola dan konsumen yang telah tertuang di karcis parkir, yakni, "Pengelola parkir tidak bertanggung jawab terhadap kehilangan barang dan/atau kendaraan", dan dengan berbagai macam kalimat yang mengandung makna yang sama. ${ }^{1}$ Pencantuman klausula yang tersebut di atas merupakan salah satu bentuk dari klausula baku yang berarti bahwa, "setiap aturan atau ketentuan dan syarat-syarat yang telah dipersiapkan dan ditetapkan terlebih dahulu secara sepihak oleh pelaku usaha yang dituangkan dalam suatu dokumen dan atau perjanjian yang mengikat dan wajib dipenuhi oleh konsumen. Ketentuan dan persyaratan tentang pencantuman klausula baku merupakan salah satu wujud keseimbangan dalam hal kedudukan antara konsumen dan pelaku usaha berdasarkan

\footnotetext{
1 Basri, "Perlindungan Hukum terhadap Konsumen Parkir", Perspektif, Volume XX, Nomor 1 (Januari, 2015), Hlm 41.
} 
prinsip kebebasan berkontrak. Kemudian, ketentuan ini merupakan upaya dalam mencegah munculnya berbagai tindakan yang merugikan konsumen karena faktor ketidaktahuan, kedudukan yang tidak seimbang, dan sebagainya yang dapat dimanfaatkan oleh pelaku usaha untuk memperoleh keuntungan dengan jalan melanggar hukum. ${ }^{2}$ Konsumen merupakan pihak yang seringkali dirugikan dalam suatu hubungan kerjasama tersebut. Karena kedudukan pelaku usaha dan konsumen tidak seimbang, dimana konsumen berada pada posisi yang lemah yang menjadi obyek aktifitas bisnis untuk meraup keuntungan yang sebesarbesarnya oleh pelaku usaha melalui pelayanan jasa parkir tersebut. ${ }^{3}$ Dalam praktik penggunaan klausula baku dalam tiket parkir dalam hal adanya kehilangan barang atau kendaraan itu sendiri di lokasi parkir maka akan menjadi tanggung jawab siapa, menilik kenyataan bahwa pengelola maupun penjaga parkir menolak bertanggung jawab dan berlindung pada klausula baku yang telah tertera maupun tidak tertera dalam tiket parkir tersebut. Lalu bagaimana perlindungan hukum bagi konsumen jika ada kehilangan barang atau kendaraan di lokasi parkir.

Seperti hasil penelitian, ${ }^{4}$ Perusahaan Daerah parkir Kota Denpasar dalam hal memberikan pelayanan parkir dan memberikan ganti kerugian terhadap konsumen yang kehilangan kendaraannya. Diatur dalam Peraturan Daerah tentang kewajiban bagi Perusahaan Daerah untuk memberikan ganti rugi secara terbatas atas kerugian konsumen dengan ketentuan harus melengakapi beberapa persyaratan.

2 Moch. Choirul Rizal, “Sanksi Tindak Pidana Pencantuman Klausula Baku Pada Karcis Parkir Kendaraan Bermotor", Al-Daulah: Jurnal Hukum dan Perundangan Islam, Volume 3, Nomor 2 (Edisi Oktober, 2013), Hlm 302.

3 Susilowati S Dajan, Hukum Perlindungan Konsumen, Universitas Terbuka, Cet. Kedua, Tangerang Selatan, 2016, Hlm 4.22.

${ }^{4}$ Ni Nyoman Ismayani, dkk, "Perlindungan Hukum Terhadap Konsumen Jasa Parkir dalam Hal Terjadinya Kehilangan Terhadap Kendaraan", Kertha Semaya: Journal Ilmu Hukum, [S1] Nov. 2013. ISSN 2303-0569. https//ojs.unud.ac.id/index.php/kerthasemaya. Diakses pada tanggal 3 Maret 2020. 


\section{METODOLOGI}

Jenis penelitian yang digunakan dalam penelitian ini adalah penelitian Normatif. Penelitian hukum normatif yaitu penelitian hukum yang mengkaji hukum tertulis dari aspek teori, sejarah, filosofi, perbandingan, struktur dan komposisi, lingkup dan materi, penjelasan umum dari pasal demi pasal, formalitas dan kekuatan mengikat suatu undang-undang tetapi tidak mengikat aspek terapan atau implementasinya. ${ }^{5}$ Pendekatan yang digunakan dalam penelitian ini adalah Pendekatan Perundang-Undangan (statute approach). Tujuan dari penelitian ini untuk mengetahui bentuk perlindungan hukum bagi konsumen jasa parkir ditinjau dari hukum positif.

\section{PEMBAHASAN}

Bentuk perlindungan hukum bagi konsumen pengguna jasa parkir maka yang pertama diketahui yaitu hubungan hukum antara konsumen pengguna jasa parkir dengan pihak pengelola parkir untuk mengetahui hak dan kewajiban. Hak dan kewajiban hukum antara satu pihak terhadap pihak lain, dapat muncul karena dari adanya hubungan hukum kedua belah pihak yang disebut perikatan. Berdasarkan Pasal 1233 KUH Perdata yang menegaskan bahwa perikatan lahir karena suatu perjanjian atau karena undang-undang yang dimana Pasal 1313 KUH Perdata menegaskan bahwa suatu persetujuan ialah suatu perbuatan yang satu orang atau lebih mengikatkan diri terhadap satu orang lain atau lebih. Sedangkan perikatan yang timbul karena hukum (undang-undang),

${ }^{5}$ Abdul kadir Muhammad, Hukum dan Penelitian Hukum, PT. Citra Aditya Bakti, Bandung, 2004, Hlm 101. 
timbul karena perbuatan baik itu perbuatan yang sesuai dengan hukum maupun yang melanggar hukum.

Pada Pasal 1352 KUH Perdata menegaskan bahwa perikatan lahir karena undang-undang, timbul dari undang-undang sebagai akibat perbuatan orang. Dalam Pasal 1353 KUH Perdata menegaskan bahwa perikatan lahir dari undang-undang sebagai akibat perbuatan orang, muncul dari suatu perbuatan yang sah atau perbuatan yang melanggar hukum. Dengan demikian dapat dikatakan bahwa perikatan lahir karena suatu perjanjian, atau karena undang-undang. Apabila adanya perikatan itu akibat berlakunya aturan tertentu, atau perbuatan seseorang baik yang sah maupun melawan hukum.

Berdasarkan KUH Perdata, di dalam melakukan sebuah perjanjian terdapat beberapa asas yang menjadi landasan pelaku usaha membuat perjanjian antara pelaku usaha/pengelola parkir dengan konsumen, salah satunya asas kebebasan berkontrak, asas kebebasan berkontrak yang sering disebut dengan asas terbuka. Asas terbuka adalah kebebasan yang diberikan oleh undang-undang kepada masyarakat untuk melakukan perjanjian, perjanjian tersebut mengikat kedua belah pihak dan merupakan undang-undang bagi mereka yang membuatnya, sepanjang tidak melanggar peraturan Perundang-undangan. Dasar hukum dari kebebasan berkontrak ini adalah Pasal 1338 Ayat (1) KUH Perdata yang berbunyi "semua persetujuan yang dibuat secara sah, berlaku sebagai undang-undang bagi mereka yang membuatnya".

Dari sekian banyak kebebasan yang diberikan kepada masyarakat, yang akan membuat perjanjian berdasarkan adanya asas kebebasan berkontrak, maka kebebasan yang erat hubungannya dan seringkali terpengaruh dengan pencatuman suatu syarat tertentu di dalam suatu perjanjian adalah adanya kebebasan untuk menentukan isi perjanjian yang akan mereka buat. Hal ini, untuk selanjutnya, akan berpengaruh 
pada adanya kebebasan berkontrak untuk membuat perjanjian dalam bentuk tertentu atau tidak. ${ }^{6}$

Berdasarkan KUH Perdata ada beberapa hubungan hukum yang merupakan keterkaitan mengenai perparkiran. Hubungan hukum yang terjadi antara konsumen dengan Pengelola parkir dapat dibagi menjadi tiga, yaitu:

\section{Hubungan Penitipan Barang}

Pada umumnya konstruksi hukum yang berlaku dalam perparkiran adalah perjanjian penitipan barang. Perjanjian penitipan barang sendiri diatur di dalam Pasal 1694 KUH Perdata yang berbunyi: ${ }^{7}$

"Penitipan barang terjadi bila orang menerima barang orang lain dengan janji untuk menyimpannya dan kemudian mengembalikannya dalam keadaan yang sama".

Menurut pengertian pasal itu, penitipan adalah suatu perjanjian "riil" yang berarti bahwa ia baru terjadi dengan dilakukannya suatu perbuatan yang nyata, yaitu diserahkannya barang yang dititipkan, jadi tidak seperti perjanjian-perjanjian lain pada umumnya yang lazimnya adalah konsensual, yaitu sudah dilahirkan pada saat tercapainya sepakat tentang hal-hal yang pokok dari perjanjian itu.

Dalam Pasal 1706 KUH Perdata diwajibkan bagi penerima titipan mengenai perawatan barang yang dipercayakan kepadanya, memeliharanya dengan minat yang sama seperti ia memelihara barang miliknya sendiri dengan demikian tanggung jawab terhadap barang yang dititipkan berada pada penerima titipan dengan tanggung jawab yang sebesar-besarnya. Hal ini sudah sesuai dengan isi Pasal 1713 Ayat (1) KUH Perdata yang menyatakan bahwa penerima titipan diwajibkan

${ }^{6}$ Kelik Wardiono, Perjanjian Baku, "Klausula Eksenorasi dan Konsumen", Ombak, Yogyakarta, 2014, Hlm 9

7 Subekti, Aneka Perjanjian, Citra Adhitya Bakti, Bandung, 1995, Hlm 107. 
mengembalikan barang yang sama dengan barang yang telah diterimanya.

Berdasarkan uraian di atas, tanggung jawab pengelola parkir terhadap konsumen parkir adalah untuk mengembalikan kendaraan konsumen dalam keadaan semula, atau dengan kata lain apabila terjadi kerusakan dan bahkan kehilangan kendaraan di areal parkir adalah merupakan tanggung jawab penerima titipan tersebut.

Hubungan penitipan barang inilah umumnya yang berlaku di dalam praktek perparkiran yang menggunakan tarif perjam. Karena hubungan hukum yang terjadi antara pemilik kendaraan sebagai pengguna jasa parkir dan pengelola parkir sebagai penyedia tempat parkir adalah hubungan penitipan barang, maka berdasarkan Pasal 1706 dan 1704 Ayat (1) KUH Perdata tersebut pengelola parkir bertanggung jawab atas terjadinya kerusakan atau kehilangan kendaraan di areal parkir yang di kelolanya.

\section{Hubungan Sewa Menyewa}

Salah satu hubungan antara pengelola parkir dan konsumen adalah hubungan sewa menyewa. Sewa menyewa diatur dalam Pasal 1548 KUH Perdata yang berbunyi: ${ }^{8}$

"Sewa menyewa ialah suatu perjanjian, dengan mana pihak yang satu mengikatkan dirinya untuk memberikan pihak yang lainnya kenikmatan dari suatu barang, selama suatu waktu tertentu dan dengan pembayaran sesuatu harga, yang oleh pihak tersebut belakangan itu disanggupi pembayarannya".

Hubungan hukum sewa menyewa dalam perparkiran biasanya baru timbul apabila ada perjanjian pokoknya yaitu perjanjian sewa menyewa ruangan gedung dan dalam perjanjian sewa menyewa parkir ini adalah perjanjian assesoir yang tunduk dan mengikuti perjanjian pokoknya.

\footnotetext{
8 Ibid., Hlm 107-108
} 


\section{Hubungan Sewa Menyewa Tidak Murni}

Dalam hubungan hukum perparkiran unsur-unsur sewa menyewa yang terdapat dalam Bab ke Tujuh KUH Perdata, tentang Sewa Menyewa tidak semuanya terpenuhi adalah pemeliharaan oleh penyewa lahan perparkiran seperti yang terdapat dalam Pasal 1563 KUH Perdata. Hal ini diakibatkan karena dalam hubungan sewa menyewa parkir pemilik kendaraan yang menyewa lahan parkir tidak serta merta menguasai lahan yang disewa selama jangka waktu sewa dalam arti setelah memarkirkan kendaraan penyewa langsung meninggalkan lahan parkir dan, konstruksi sewa menyewa ini adalah sewa menyewa tidak murni sehingga apabila terjadi kehilangan atau kerugian atas kendaraan di lahan yang disewa, maka penyewa masih mempunyai hak untuk menuntut ganti rugi kepada pihak yang menyewakan lahan karena walaupun lahan parkir telah disewakan kepada konsumen, namun penguasaan lahan parkir tetap pada pihak yang menyewakan (pengelola parkir). ${ }^{9}$

Hal lain yang menyebabkan terjadi sewa menyewa tidak murni dalam perparkiran adalah penyewa (pemilik kendaraan) tidak bisa bebas mempergunakan lahan yang disewanya karena peraturan yang ketat dari yang menyewakan, misalnya harus masuk dan keluar dari pintu tertentu, harus parkir paralel, tidak boleh parkir miring dan peraturan lain terhadap obyek sewa.

Hal ini sangat berbeda dengan sewa menyewa rumah dan tanah seperti yang terdapat di dalam KUH Perdata dimana penyewa rumah memiliki kekuasaan penuh terhadap rumah yang dikuasainya selama jangka waktu sewa. Dengan kata lain pemilik rumah (yang menyewakan) tidak berhak menguasai atau menempati rumah tersebut selama masa sewa serta tidak berhak mengatur penyewa dalam

9 Ibid., Hlm 108-109 
menggunakan lahan sewanya. Berdasarkan hal tersebut, maka apabila terjadi kehilangan atau kerusakan di dalam rumah selama jangka waktu sewa tidak dapat dimintai tanggungjawab kepada pemilik. Hal tersebut menjadi pengertian di dalam melakukan hubungan hukum antara konsumen dengan pengelola parkir mengenai sewa menyewa tidak murni.

Dalam perjanjian penitipan barang tanggung jawab pengelola parkir terhadap konsumen pengguna jasa parkir adalah memelihara barang titipan itu dengan sebaik-baiknya seperti memelihara barangbarang kepunyaan sendiri serta mengembalikan barang/kendaraan dalam keadaan semula.

Menurut ketentuan pasal tersebut, bahwa kewajiban dari pengelola parkir itu adalah menyerahkan barang sewaan kepada penyewa, memelihara barang sewaan bagi penyewa selama masa sewa. Dikaitkan dengan perjanjian jasa parkir maka jika perjanjiannya dianggap sebagai perjanjian sewa menyewa yang diatur di dalam KUH Perdata yang tidak dapat terpenuhi secara baik dalam perjanjian parkir, sebab konsumen pengguna jasa parkir yang menyewa lahan parkir tidak serta merta menguasai lahan yang disewa selama jangka waktu sewa. Pengelola parkir tetap mempunyai tanggung jawab terhadap barang-barang dan kendaraan yang diparkir pada lokasi parkir.

Dalam melakukan perjanjian pengguna jasa yang menggunakan jasa parkir harus menyetujui apa yang menjadi syarat dan ketentuan pihak pengelola parkir, apabila konsumen atau pengguna jasa setuju mereka akan menandatangani perjanjian yang telah ditentukan terlebih dahulu oleh pengelola parkir. Kecakapan dalam melakukan perjanjian, dalam melakukan perjanjian yang boleh melakukan perjanjian adalah yang dewasa dan tidak di bawah pengampuan. 
Jenis perjanjiannya sendiri pengelola parkir sering mencantumkan perjanjian baku atau klausula baku pada karcis/tiket parkir yang diterima oleh konsumen, yang berbunyi “segala kerusakan dan kehilangan bukan tanggung jawab pengelola parkir", atau dengan kalimat lain yang bermakna sama. Hal tersebut merupakan perjanjian yang sudah ditentukan terlebih dahulu isi perjanjiannya oleh pengelola parkir. Perjanjian tersebut dapat dikatakan tidak sah atau batal karena ada dua syarat yang bertentangan dengan Pasal 1320 KUH Perdata yaitu kata sepakat dan cakap. Kata sepakat harus dilakukan dengan penuh kesadaran di antara para pembuatnya, yang bisa diberikan secara lisan dan tertulis. Sedangkan cakap disini merupakan hal yang sangat perlu diperhatikan, jika tidak cakap seorang konsumen yang melakukan perjanjian maka perjanjian dapat dikatakan batal, karena setiap konsumen yang datang untuk parkir ada berbagai kalangan, dari kalangan remaja hingga dewasa sehingga pengelola parkir juga tidak dapat mengenali konsumen yang sudah cakap dengan yang belum cakap.

Dan selain itu, perlindungan hukum terhadap konsumen juga diatur dalam Pasal 4 huruf a Undang-Undang Nomor 8 Tahun 1999 Tentang Perlindungan Konsumen mempunyai hak untuk mendapatkan keselamatan, keamanan, dan kenyamanan dalam menikmati jasa yang ditawarkan. Namun dalam pelaksanaan di lapangan pelaku usaha atau pengelola parkir belum memberikan rasa aman sesuai pasal tersebut dan konsumen yang merasa dirugikan berhak mendapat ganti rugi berdasarkan Pasal 4 huruf h Undang-Undang Perlindungan Konsumen yang berbunyi "hak untuk mendapatkan kompensasi, ganti rugi dan/atau penggantian, apabila barang dan/atau jasa yang diterima tidak sesuai dengan perjanjian atau tidak sebagaimana mestinya". 
Pasal 19 Undang-Undang Perlindungan Konsumen tentang tanggung jawab pelaku usaha tercantum bahwa pelaku usaha bertanggung jawab memberikan ganti rugi atas kerusakan akibat menggunakan barang dan/atau jasa. Undang-Undang Nomor 8 Tahun 1999 Tentang Perlindungan Konsumen telah diterbitkan dengan jelas, namun proses pelaksanaannya belum maksimal dengan kata lain peraturan yang ada dalam undang-undang tidak sesuai dengan praktek di lapangan. Dalam beberapa kasus banyak ditemukan pelanggaran-pelanggaran yang merugikan para konsumen. Contohnya, dari lembaran karcis/tiket parkir yang pernah dicantumkan oleh pengelola parkir tertulis klausula baku yang berisi klausula eksonerasi.

Hal ini bertentangan dengan Undang-Undang Nomor 8 Tahun 1999 Tentang Perlindungan Konsumen. Dalam Pasal 18 Ayat (1) huruf a, bahwa pelaku usaha dilarang menyatakan pengalihan tanggung jawab pelaku usaha kepada konsumen. Larangan dan persyaratan tentang penggunaan klausula baku dimaksudkan untuk menempatkan kedudukan konsumen setara dengan pelaku usaha berdasarkan prinsip kebebasan berkontrak dan mencegah kemungkinan timbulnya tindakan yang merugikan konsumen karena faktor ketidaktahuan, kedudukan yang tidak seimbang, dan sebagainya yang mungkin dapat dimanfaatkan oleh pelaku usaha untuk memperoleh keuntungan.

Kebanyakan pengelola parkir menggunakan perjanjian baku untuk menghindari kerugian akibat masalah yang diderita konsumen pengguna jasa parkir, akan tetapi perjanjian baku yang biasanya dicantumkan oleh pengelola parkir merupakan hal yang salah di dalam Undang-Undang Perlindungan Konsumen, itu karena perjanjian baku menurut Pasal 46 Ayat (1) Undang-Undang Perlindungan Konsumen adalah pencantuman klausula baku termasuk perbuatan yang dapat 
diancam dengan pidana penjara paling lama 5 (lima) tahun atau pidana denda paling banyak Rp 2.000.000.000,00 (dua miliar rupiah).

Dari sekian banyak perjanjian baku yang terdapat di dalam masyarakat, menurut Badrulzaman, sebenarnya dapat dibagi menjadi: ${ }^{10}$

a. Perjanjian baku sepihak (perjanjian standar umum), yaitu perjanjian yang isinya ditentukan oleh pihak yang kuat kedudukannya di dalam perjanjian itu. Pihak yang kuat dalam hal ini adalah kreditur yang lazimnya mempunyai posisi (ekonomi) lebih kuat dibandingkan dengan pihak debitur.

b. Perjanjian baku yang diterapkan oleh pemerintah (perjanjian baku khusus), yaitu perjanjian yang isinya ditentukan oleh pemerintah terhadap perbuatan-perbuatan hukum tertentu, baik adanya dan berlakunya perjanjian ini untuk para pihak yang ditetapkan secara sepihak oleh pemerintah.

c. Perjanjian baku yang ditentukan di lingkungan notaris atau advokat adalah perjanjian yang konsepnya sejak semula sudah disediakan untuk memenuhi permintaan masyarakat yang meminta bantuan pada mereka.

Dengan berlakunya Undang-Undang Perlindungan Konsumen Nomor 8 Tahun 1999 Tentang Perlindungan Konsumen, maka terdapat pembatasan yang relatif lebih tegas terdapat pencantuman klausula baku dan klausula eksonerasi. Hal tersebut sebagaimana ditetapkan di dalam Pasal 18 Ayat (4) Undang-Undang Perlindungan Konsumen, "Pelaku usaha wajib menyesuaikan klausula baku yang bertentangan dengan undang-undang ini". ${ }^{11}$

Hal ini dapat dilihat dalam ketentuan Pasal 18 Ayat (1) dan (2) Undang-Undang Perlindungan Konsumen, yang menetapkan:

(1) Pelaku usaha dalam menawarkan barang dan/atau jasa yang ditujukan untuk diperdagangkan dilarang membuat atau mencantumkan klausula baku pada setiap dokumen dan/atau perjanjian apabila:

a. Menyatakan pengalihan tanggung jawab pelaku usaha;

${ }^{10}$ Kelik Wardiono, Op., Cit., Hlm 12

${ }_{11}$ Ibid., Hlm 16 
b. Menyatakan bahwa pelaku usaha berhak menolak penyerahan kembali barang yang dibeli konsumen;

c. Menyatakan bahwa pelaku usaha berhak menolak penyerahan kembali uang yang dibayarkan atas barang dan/atau jasa yang dibeli oleh konsumen;

d. Menyatakan pemberian kuasa dari konsumen kepada pelaku usaha baik secara langsung maupun tidak langsung untuk melakukan segala tindakan sepihak yang berkaitan dengan barang yang dibeli oleh konsumen secara angsuran;

e. Mengatur perihal pembuktian atas hilangnya kegunaan barang atau pemanfaatan jasa yang dibeli oleh konsumen;

f. Memberi hak kepada pelaku usaha untuk mengurangi manfaat jasa atau mengurangi harta kekayaan konsumen yang menjadi obyek jual beli jasa;

g. Menyatakan tunduknya konsumen kepada peraturan yang berupa aturan baru, tambahan, lanjutan dan/atau pengubahan lanjutan yang dibuat sepihak oleh pelaku usaha dalam masa konsumen memanfaatkan jasa yang dibelinya;

h. Menyatakan bahwa konsumen memberi kuasa kepada pelaku usaha untuk pembebanan hak tanggungan, hak gadai, atau hak jaminan terhadap barang yang dibeli oleh konsumen secara angsuran.

(2) Pelaku usaha dilarang mencantumkan klausula baku yang letak atau bentuknya sulit terlihat atau tidak dapat dibaca secara jelas, atau yang pengungkapannya sulit dimengerti.

Berdasarkan isi di atas, maka dapat disimpulkan bahwa bentuk perlindungan hukum bagi konsumen jasa parkir berdasarkan Undang-Undang Perlindungan Konsumen, dimana pengelola parkir wajib menjamin keamanan dan keselamatan obyek perjanjian penitipan barang selama jangka waktu tersebut. Apabila terjadi kerusakan atau kehilangan obyek penitipan barang tersebut, maka pengelola parkir wajib bertanggung jawab untuk memberikan ganti rugi, dimana bentuk tanggung jawab tersebut diatur dalam beberapa instrumen hukum diantaranya KUH Perdata dan Undang-Undang Perlindungan Konsumen.

Sehingga ketika konsumen merasa dirugikan oleh pelaku usaha Cara penyelesaian sengketa konsumen telah diatur dalam Pasal 45 
sampai dengan Pasal 48 Undang-Undang Perlindungan Konsumen. Dalam Ayat (1) diatur penyelesaian sengketa melalui pengadilan umum. Penyelesaian sengketa konsumen sebagaimana dimaksud pada Pasal 45 Ayat (2) Undang-Undang Perlindungan Konsumen, dimana tidak menutup kemungkinan dilakukannya penyelesaian gugatan secara damai oleh para pihak-pihak yang bersengketa.

Upaya hukum yang dilakukan oleh konsumen parkir yang dirugikan dapat mengajukan tuntutan sesuai dengan UndangUndang Perlindungan Konsumen Pasal 45 Ayat (1) “setiap konsumen yang dirugikan dapat menggugat pelaku usaha melalui lembaga yang bertugas menyelesaikan sengketa antara konsumen dengan pelaku usaha atau melalui peradilan yang berada di lingkungan peradilan umum". Ayat (2) "penyelesaian sengketa konsumen dapat ditempuh melalui peradilan atau di luar pengadilan berdasarkan pilihan sukarela para pihak yang bersengketa".

Dalam hal tuntutan yang boleh melakukan tuntutan diatur pula dalam Undang-Undang Perlindungan Konsumen Pasal 46 Ayat (1) “gugatan atas pelanggaran pelaku usaha dapat dilakukan oleh:

a. Seorang konsumen yang dirugikan atau ahli waris yang bersangkutan;

b. Kelompok konsumen yang mempunyai kepentingan yang sama;

c. Lembaga perlindungan konsumen swadaya masyarakat yang memenuhi syarat, yaitu berbentuk badan hukum atau yayasan, yang dalam anggaran dasarnya menyebutkan dengan tegas bahwa tujuan didirikannya organisasi tersebut adalah untuk kepentingan perlindungan konsumen dan telah melaksanakan kegiatan sesuai dengan anggaran dasarnya;

d. Pemerintah dan/atau instansi terkait apabila barang dan/atau jasa yang dikonsumsi atau dimanfaatkan mengakibatkan kerugian materi yang besar dan/atau korban yang tidak sedikit."

Serta Pasal 46 Ayat (2) "gugatan yang diajukan oleh sekelompok konsumen, lembaga perlindungan konsumen swadaya masyarakat 
atau pemerintah sebagaimana dimaksud pada Ayat (1) huruf b, huruf c, dan huruf d diajukan kepada peradilan umum.

Penyelesaian sengketa dapat diselesaikan melalui dua jalur, antara lain:

1. Non Litigasi

Non litigasi adalah penyelesaian sengketa di luar pengadilan. Penyelesaian sengketa konsumen di luar pengadilan antara lain:

a. BPKN (Badan Perlindungan Konsumen Nasional)

b. BPSK (Badan Penyelesaian Sengketa Konsumen)

c. LPKSM (Lembaga Perlindungan Konsumen Swadaya Masyarakat)

\section{Litigasi}

Secara konvensional, penyelesaian sengketa dalam dunia bisnis, seperti dalam perdagangan, perbankan, proyek pertambangan, minyak dan gas, energi, infrastruktur, dan sebagainya dilakukan melalui proses litigasi. Dalam proses litigasi menempatkan para pihak saling berlawanan satu sama lain, selain itu penyelesaian sengketa secara litigasi merupakan sarana akhir (ultimum remidium) setelah alternatif penyelesaian sengketa lain tidak membuahkan hasil. ${ }^{12}$

\section{SIMPULAN}

Bentuk perlindungan hukum bagi konsumen jasa parkir ditinjau dari hukum positif, bahwa pengelola parkir wajib menjamin keamanan dan keselamatan obyek perjanjian penitipan barang selama jangka waktu tetentu. Dalam KUHPerdata apabila terjadi kerusakan atau kehilangan obyek penitipan barang, maka pengelola parkir wajib bertanggung jawab untuk memberikan ganti rugi. Hubungan hukumnya lahir melalui perjanjian penitipan barang bukan perjanjian penyewaan lahan. Perjanjian penitipan barang, tanggung jawab pengelola parkir terhadap konsumen pengguna jasa parkir adalah memelihara barang titipan itu dengan sebaikbaiknya seperti memelihara barang-barang kepunyaan sendiri serta mengembalikan barang/kendaraan dalam keadaan semula. Sedangkan

\footnotetext{
12 Frans Hendra Winarta, Hukum Penyelesaian Sengketa, Sinar Grafika, Jakarta, 2012, Hlm 1-2.
} 
dalam Undang-Undang Perlindungan Konsumen diatur pula terkait hak konsumen untuk mendapatkan keselamatan, keamanan, dan kenyamanan dalam menikmati jasa yang ditawarkan. Apabila dirugikan, maka setiap konsumen dapat menggugat pelaku usaha melalui lembaga yang bertugas menyelesaikan sengketa, antara konsumen dengan pelaku usaha atau melalui peradilan yang berada di lingkungan peradilan umum.

\section{DAFTAR PUSTAKA}

Abdulkadir Muhammad, 2004, Hukum dan Penelitian Hukum". PT. Citra Aditya Bakti, Bandung.

Frans Hendra Winarta, 2012, Hukum Penyelesaian Sengketa", Sinar Grafika, Jakarta.

Kelik Wardiono, 2014, Perjanjian Baku, Klausula Eksenorasi Dan Konsumen", Ombak, Yogyakarta.

Subekti, 1995, Aneka Perjanjian, Citra Adhitya Bakti, Bandung.

Susilowati S Dajaan, 2016, Hukum Perlindungan Konsumen, Cet. 2, Universitas Terbuka, Tangerang Selatan.

Basri, Perlindungan Hukum Terhadap Konsumen Parkir", Jurnal Perspektif, Volume XX, Nomor 1 (Januari, 2015), Hlm 41

Moch. Choirul Rizal, Sanksi Tindak Pidana Pencantuman Klausula Baku Pada Karcis Parkir Kendaraan Bermotor," Jurnal Hukum dan Perundangan Islam Al-Daulah:, Volume 3, Nomor 2 (Edisi Oktober, 2013), Hlm 302

Ni Nyoman Ismayani, dkk, Perlindungan Hukum Terhadap Konsumen Jasa Parkir Dalam Hal Terjadinya Kehilangan Terhadap Kendaraan: https//ojs.unud.ac.id/index.php/kerthasemaya.: Journal Ilmu Hukum, Kertha Semaya, [S1] Nov. 2013. ISSN 2303-0569. diakses pada tanggal 3 Maret 2020. 
Kitab Undang-Undang Hukum Perdata, Lembaran Negara Republik Indonesia Tahun 1975 Nomor 12.

Undang-Undang Nomor 8 Tahun 1999 Tentang Perlindungan Konsumen, Lembaran Negara Republik Indonesia Tahun 1990 Nomor 42. 